\title{
ANALISIS SISTEM PENGEMBANGAN SDM MELALUI PENDEKATAN TRAINING, STUDI PADA PT. TRIDHARMA KENCANA
}

Oleh:

\author{
Eko Setiobudi \\ Sekolah Tinggi Ilmu Ekonomi Tribuana Bekasi \\ Email: \\ ekosetiobudi@gmail.com
}

\begin{abstract}
ABSTRAK
Globalisasi mendorong adanya kompetisi organisasi sehingga mampu merebut market share yang lebih besar. Kompetisi juga terletak pada kompetensi, dimana pengembangan SDM menjadi bagian penting guna mendorong organisasi dapat semakin kompetitif. Tujuan penelitian ini adalah untuk melihat sejauh mana efektifitas training yang berjalan di PT. Tridharma Kencana sebagai bagian dari skema pengembangan karyawan. Penelitian ini adalah pendekatan kualitatif deskriptif. Pengambilan data primer melalui wawancara dan observasi. Data sekunder adalah data-data perusahaan yang diberikan kepada peneliti, maupun buku, dan jurnal. Pengambilan sampel dilakukan secara purposif dengan jumlah sampel sebanyak 20 orang. Pengumpulan melalui wawancara, observasi. Analisis data dilakukan dengan reduksi data, menyajikan data, dan membuat kesimpulan. Pengembangan SDM di PT. Tridharma Kencana, terdiri dari dua tahap, yakni pengembangan yang meliputi, Metode Understudy, Metode Job Rotasi, Metode Coaching-Counseling. Tahap kedua yakni training, sebagai tindak lanjut untuk meningkatkan kompetensi karyawan. Efektifitas dan kualitas training, maka dilakukan evaluasi, yang meliputi empat level evaluasi, yakni : Evaluasi level 1 (reaction), Level 2 (Learning), Level 3 (Behavior), dan Level 4 (result).Pelaksanaan training di PT. Tridharma Kecana selama semester I/2016 sebaknya 49 kali. Efektifitas dan kualitasnyapun dapat dilihat cukup baik, karena dalam melakukan evaluasi juga melibatkan atasan karyawan untuk melakukan penilaian, sehingga lebih independen dan kredibel.
\end{abstract}

Kata Kunci: Evaluasi, Pengembangan, SDM, Training.

\section{A. PENDAHULUAN}

Sumber Daya Manusia (SDM) yang notabene adalah karyawan adalah aset utama bagi sebuah orgaisasi atau perusahaan. Oleh sebab itu, pengelolaan dan pengembangan karyawan menjadi bagian penting dalam rangka mendorong kemajuan perusahaan. 
Pada era globalisasi dimana lalu lintas orang dan informasi tidak lagi di batasi oleh ruang, jarak dan waktu, maka kinerja organisasi juga akan sangat bergantung dari kinerja SDM-nya. Persaingan bebas yang menjadi salah satu kata kunci dari globalisasi juga berdampak pada persaingan SDM, sehingga hanya SDM yang memiliki kompetensi dan keunggulan kompetitif yang dipastikan dapat memenangkan sebuah persaingan. Kontekstualisasi inilah, peranan SDM menjadi salah satu kata kunci bagi organisasi atau perusahaan untuk dapat memenangkan persaingan global yang sudah berjalan sedemikian kompetitif.

Penekanan pada aspek Sumber Daya Manusia (SDM) sebagai modal berharga dalam organisasi mencerminkan peranan lebih pada sumber daya tak berwujud dari pada yang nyata. Sebagaimana yang dikemukakan oleh (Becker, Huselid, \& Ulchich, 2001) bahwa investasi sumber daya manusia bertujuan untuk mendapatkan keuntungan bagi organisasi atau perusahaan baik dalam jangka panjang atau pendek. Melalui kompetensi yang sesuai dengan job requarment, yang terimplementasikan dalam keterampilan, keahilian dan kemampuan yang dimiliki oleh karyawan, sehingga diharapkan akan termotivasi untuk terus belajar membangun dan memberikan supporting sistem bagi keungulan komparatif organisasi atau perusahaan pada lingkungan bisnis yang lebih unggul dalam berkopetisi. Dalam hal inilah, (Wright, Moynihan, \& Allen, 2005) menyebut bahwa sumber daya manusia digunakan secara signifikan sebagai penggerak sumber daya lain dan memiliki posisi strategis yang berkontribusi untuk mewujudkan kinerja organisasi perusahaan dengan keunggulan kompetitif.

Hal yang sama juga dikemukakan oleh (Paul \& R.N, 2003), yang menegaskan bahwa pengembangan sumber daya manusia memiliki hubungan langsung dengan profitabilitas organisasi. Oleh karena itu, setiap organisasi disarankan untuk mengoptimalkan kinerja karyawan dalam memberikan kontribusi yang optimal, antara lain dengan cara melakukan program pelatihan dan pengembangan. Hal ini juga berhubungan dengan produktivitas organisasi dan dapat meningkatkan efektivitas dan efisiensi pekerjaan.

Dalam konteks inilah, pengembangan kompetensi karyawan baik secara soft skill kompetensi maupun hard skill kompetensi menjadi sangat penting. Bagaimanapun pengembangan SDM yang berbasis kompetensi harus dilakukan agar dapat memberikan hasil sesuai dengan tujuan dan sasaran organisasi dengan standar kinerja yang telah ditetapkan. Kompetensi yang dimiliki seorang karyawan secara individual harus dapat mendukung pelaksanaan visi misi organisasi melalui kinerja strategis organisasi tersebut.

Untuk itu, beragam pengembangan kompetensi karyawan harus terus dilakukan oleh arganisasi atau perusahaan dalam rangka mengoptimalkan SDM sebagai mesih penggerak sumber daya organisasi. Beragam pendekatan tersebut diantaranya adalah pelatihan atau training, retensi, benefit dan salary dan beragam program lainnya.

Pelatihan dan pengembangan itu sendiri, merupakan dua konsep yang sama, yaitu untuk meningkatkan pengetahuan, keterampilan, dan kemampuan. Tetapi, dilihat dari tujuannya, umumnya kedua konsep tersebut dapat dibedakan. Pelatihan lebih ditekankan pada peningkatan kemampuan untuk malakukan pekerjaan yang spesifik pada saat ini, dan pengembangan lebih ditekankan pada peningkatan 
pengetahuan untuk melakukan pekerjaan pada masa yang akan datang, yang dilakukan melalui pendekatan yang terintegrasi dengan kegiatan lain untuk mengubah perilaku kerja.

Dengan demikian, pelatihan bagi karyawan merupakan sebuah proses mengajarkan pengetahuan dan keahlian tertentu serta sikap agar karyawan semakin terampil dan mampu melaksanakan tanggung jawabnya dengan semakin baik, sesuai dengan standar. Sedangkan pengembangan memiliki ruang lingkup lebih luas. Dapat berupa upaya meningkatkan pengetahuan yang mungkin digunakan segera atau sering untuk kepentingan di masa depan. Pengembangan sering dikategorikan secara eksplisit dalam pengembangan manajemen, organisasi, dan pengembangan individu karyawan. Penekanan lebih pokok adalah pada pengembangan manajemen. Dengan kata lain, fokusnya tidak pada pekerjaan kini dan mendatang, tetapi pada pemenuhan kebutuhan organisasi jangka panjang.

Penelitian ini akan dilakukan di PT. Tridharma Kencana, yakni sebuah perusahaan Electronic Manufacturing Services (EMS) yang selama ini mengerjakan melakukan perakitan terhadap produk-produk elektronik dan telekomunikasi, seperti LED TV, Smartphone, Modem dan lain sebagainya. Dengan jumlah karyawan yang cukup banyak, dan sudah beroperasi selama puluhan tahun, maka pemilihan PT. Tridharma Kencana sebagai obyek penelitian dirasakan cukup pas, untuk melakukan analisa terhadap kinerja karyawannya.

Kebanyakan pelaksanaan training di di beberapa perusahaan yang berjalan selama ini, adalah berjalannya training yang seringkali dianggap sebagai formalitas saja. Artinya, training dilakukan dan setelah training, tidak dilakukan monitoring dan kontrol serta evaluasi terhadap dampak dari penyelenggaraan training. Akibatnya training menjadi entitas yang terpisah dengan skema pengembangan SDM sebagaimana yang sudah di jelaskan tersebut di atas. Padahal idealnya, training adalah salah satu bagian dari skema pengembangan SDM, sehingga leveling dan grading karyawan yang pada ujungnya adalah mutasi serta promosi karyawan memiliki pijakan yang jelas, khususnya dari aspek komptensi karyawan, baik soft maupun hard skill kompetensi. Oleh sebab itu, training harus ditempatkan sebagai satu kesatuan sistem yang berjalan secara sistemik, efektif dan komprehensif dalam skema pengembangan SDM. Berkenaan dengan hal tersebut di atas, penelitian ini dalam rangka melihat sejauhmana training yang berjalan di PT. Tridharma Kencana menjadi bagian integral dari sistem pengembangan SDM. Maka rumusan dari penelitian ini adalah bagaimana pengembangan kompetensi karyawan melalui metode pelatihan atau training yang dilakukan di PT. Tridharma Kencana. Adapun tujuan dari penelitian ini adalah untuk melihat sejauh mana efektifitas pelaksanaan training dalam rangka pengembangan kompetensi karyawan di PT. Tridharma Kencana.

\section{B. KAJIAN PUSTAKA}

Pengembangan sumber daya manusia memiliki hubungan langsung dengan profitabilitas organisasi (Paul \& R.N, 2003). Oleh karena itu, setiap organisasi disarankan untuk mengoptimalkan kinerja karyawan dalam memberikan kontribusi 
yang optimal, antara lain dengan cara melakukan program pelatihan dan pengembangan. Hal ini juga berhubungan dengan produktivitas organisasi dan dapat meningkatkan efektivitas dan efisiensi pekerjaan.

Dalam konteks inilah, pengembangan kompetensi karyawan baik secara soft skill kompetensi maupun hard skill kompetensi menjadi sangat penting. Bagaimanapun pengembangan SDM yang berbasis kompetensi harus dilakukan agar dapat memberikan hasil sesuai dengan tujuan dan sasaran organisasi dengan standar kinerja yang telah ditetapkan. Kompetensi yang dimiliki seorang karyawan secara individual harus dapat mendukung pelaksanaan visi misi organisasi melalui kinerja strategis organisasi tersebut.

Kompetensi didefinisikan sebagai "underlying characteristic's of an individual which is causally related to criterion- referenced effective and or superior performance in a job or situation" (Spencer \& Signe, 1993). Kompetensi merupakan karakteristik yang mendasari seseorang dan berkaitan dengan efektivitas kinerja individu dalam pekerjaannya. Dengan kata lain, kompetensi dapat dipahami sebagai sebuah kombinasi antara ketrampilan (skill), atribut personal, dan pengetahuan (knowledge) yang tercermin melalui perilaku kinerja (job behavior) yang dapat diamati, diukur dan dievaluasi.

Dalam sejumlah literatur, kompetensi sering dibedakan menjadi dua tipe, yakni soft competency atau jenis kompetensi yang berkaitan erat dengan kemampuan untuk mengelola proses pekerjaan, hubungan antar manusia serta membangun interaksi dengan orang lain. Contoh soft competency adalah: leadership, communication, interpersonal relation, dan lain-lain. Tipe kompetensi yang kedua sering disebut hard competency atau jenis kompetensi yang berkaitan dengan kemampuan fungsional atau teknis suatu pekerjaan. Dengan kata lain, kompetensi ini berkaitan dengan seluk beluk teknis yang berkaitan dengan pekerjaan yang ditekuni. Contoh hard competency adalah : electrical engineering, marketing research, financial analysis, manpower planning, dan lain-lain.

Oleh karena itu kinerja individu dalam organisasi merupakan jalan dalam meningkatkan poduktivitas organisasi itu sendiri. Dan sebagaimana lazimnya di banyak organisasi ataupun perusahaan, pengembangan kompetensi karyawan, salah satunya dilakukan melalui pelaksanaan pelatihan atau training.

Menurut (Marzuki, 1992) pelatihan adalah suatu proses membantu orang lain dalam memperoleh skill dan pengetahuan. Sedangkan (Moekijat, 1990) menjelaskan istilah latihan untuk menunjukkan setiap proses untuk mengembangkan bakat, keterampilan dan kemampuan pegawai guna menyelesaikan pekerjaan-pekerjaan tertentu. Sementara (Nawawi, 1997) menyatakan bahwa pelatihan pada dasarnya adalah proses memberikan bantuan bagi para pekerja untuk menguasai keterampilan khusus atau membantu untuk memperbaiki kekurangannya dalam melaksanakan pekerjaan. Fokus kegiatannya adalah untuk meningkatkan kemampuan kerja dalam memenuhi kebutuhan tuntutan cara bekerja yang paling efektif pada masa sekarang. Dengan demikian, dapat disimpulkan bahwa latihan dan pengembangan dapat didefinisikan sebagai usaha yang terencana dari organisasi untuk meningkatkan pengetahuan, keterampilan, dan kemampuan karyawan. 
Sementara, penelitian yang dilakukan oleh (Wicaksono, 2016) dengan judul "Pengaruh Pelatihan Dan Pengembangan Sumber Daya Manusia Dalam Rangka Meningkatkan Semangat Kerja Dan Kinerja Karyawan (Studi DI SKM Unit V PT. Gudang Garam. Tbk. Kediri), menyimpulkan bahwa adanya pelatihan atau training yang baik akan memberikan peningkatan terhadap kinerja karyawan yang baik pula. Dengan demikian, dapat dikatakan bahwa tujuan pelatihan untuk mengembangkan pengetahuan, sikap, ketrampilan kerja dan moral karyawan dalam usahanya untuk meningkatkan daya saing dan produktifitas karyawan sehingga menghasilkan produk yang berkualitas.

\section{METODE PENELITIAN}

Penelitian ini menggunakan pendekatan kualitatif melalui prosedur penelitian yang menghasilkan data deskriptif sebagai jenis penelitian yang temuan-temuannya tidak diperoleh melalui prosedur statistik atau bentuk hitungan lainnya (Bogdan \& J, 1992) Penelitian kualitatif tersebut mempunyai ciri-ciri: (a) fokuspenelitiannya bersifat kompleks dan luas, (b) bermaksud untuk memberi makna atas fenomena secara holistik, dan (c) menempatkandiri peneliti secara aktif dalam seluruh proses penelitian.

Selain itu, penelitian kualitatif ini dilakukan untuk membangun pengetahuan melalui pemaknaan dan penemuan dengan menggunakan observasi terstruktur dan tidak terstruktur, interaksi komunikatif, wawancara mendalam, serta peneliti itu sendiri sebagai instrument. Relevan dengan pendapat sebelumnya, Sudjana dan Ibrahim menjelaskan ciri-ciri penelitian kualitatif adalah: (a) Sumber data menggunakan lingkungan alamiah; (b) Sifatnya deskriptif analitik yang berarti data yang diperoleh dari penelitian yang disusun peneliti di lokasi penelitian dituangkan dalam analisis data dengan memperkaya informasi; (c) Tekanan penelitian pada proses bukan pada hasil; (d) Induktif atau data yang sifat empiris dianalisis kemudian diambil kesimpulan; (e) Mengutamakan makna, artinya makna yang diungkap berkisar pada asumsi-asumsi apa yang dimiliki orang mengenai hidupnya (Sudjana \& Ibrahim, 2002).

Skema pengembangan SDM dalam penelitian ini didekati dengan analisis dengan menggunakan metode grounded theory, dimana konseptualisasi teoritis sekaligus menunjukkan bahwa para peneliti grounded theory berkonsentrasi pada "pola" aksi dan interaksi yang terjadi diantara berbagai macam unit sosial ("aktor"). Dengan demikian penelitian ini lebih menekankan pendekatan pencarian teori-teori grounded yang terkait dengan aspek sosiologis mengingat fokus penelitian adalah keterkaitan dan interaksi antar departemen dalam mengembangakan SDM dimana salah satunya dengan mengunakan training.

Pengambilan sampel penelitian dilakukan secara purposif karena dalam penelitian kualitatif apa yang akan dicari adalah masalah yang alami sehingga tidak semua orang dapat dijadikan sampel. Penelitian kualitatif juga tidak terlalu dibutuhkan random sampling atau pemilihan secara acak terhadap para partisipan atau informan dan lokasi penelitian. Karenannya pembahasan mengenai informan atau partisipan dan lokasi penelitian dapat mencakup empat aspek: (1) lokasi penelitian, (2) aktor, (3) peristiwa dan, (4) proses. Jika dikaji dari perspektif ini, sample penelitian yang dijadikan sebagai informan dalam penelitian ini terdiri 
dari beberapa kelompok, yakni: (1) Kepala Departemen; (2) Kepala Divisi dan ; (3) Manager/Asisten Manager, (4) Supervisor/Asisten Supervisor, dan (5) Leader.

Adapun pembatasan jumlah, informan atau sample sebagai sumber data/informasi atau subjek penelitian berjumlah 20 orang. Jumlah ini dianggap cukup dan sejalan dengan pendapat (Emzir, 2012), yang peneliti biasanya melakukan 20-30 wawancara perdasarkan beberapa pertemuan dilapangan untuk mengumpulkan data. Jumlah ini juga dirasa telah memadai sebab: (1) informasi yang diperoleh dari informan lain telah jenuh atau dengan kata lain hanya mengulang apa yang telah disampaikan oleh informan sebelumnya dan (2) yang terpenting dalam penelitian kualitatif, bukanlah jumlah orangnya, namun kedalaman (depth), kekayaan (richness), dan kompleksitas (complexity) informasi yang dimiliki informan. Hal ini juga sejalan dengan proses dan tekhnis penyampelan berbuka sebagaimana yang disampaikan oleh (Straus \& Corbin, 2003).

Proses pengambilan data primer yang digunakan oleh penelitian adalah hasil dari wawancara dengan informan serta observasi lapangan. Data sekunder adalah data-data perusahaan yang diberikan kepada peneliti, maupun buku, jurnal serta koran. Dalam melakukan penelitianini, peneliti menggunakan beberapa cara dalam pengumpulan data, yaitu:

1. Wawancara

Teknik wawancara adalah teknik mengumpulkan data atau informasi dengan cara bertatap muka langsung dengan informan agar mendapatkan data lengkap dan mendalam. Wawancara ini dilakukan dengan frekuensi tinggi (berulang-ulang) secara intensif (Sugiyono, 2011). Peneliti akan melakukan wawancara semi terstruktur, guna untuk mendapatkan ide-ide yang lebih terbuka dan mendalam.Oleh karena itu peneliti menyiapkan pedoman wawancara.

2. Observasi

Definisi Observasi lapangan atau pengamatan lapangan (field observation) adalah kegiatan yang setiap saat dilakukan, dengan kelengkapan panca indra yang dimiliki. Selain dengan membaca koran, mendengarkan radio, menonton televisi atau berbicara dengan orang lain, kegiatan obsevasi merupakan salah satu kegiatan untuk memahami lingkungan (Sugiyono, 2011). Peneliti akan melakukan observasi langsung dilapangan tempat lokasi penelitian. Guna dari melakukan observasi ini adalah agar peneliti dapat melihat langsung keadaan yang terjadi dalam internal dan eksternal perusahaan.

Teknik analisa data dalam penelitian kualitatif dilakukan melalui langkah-langkah : Langkah (1) mengolah dan mempersiapkan data untuk dianalisis. Langkah (2) Membaca keseluruhan data. Langkah (3) menganalisis lebih detail dengan meng-coding data. Langkah (4) terapkan proses coding untuk mendeskripsikan setting, orang-orang kategori-kategori dan tema-tema yang akan dianalisis. Langkah (5) tunjukkan bagaimana deskripsi dan tema-tema ini akan disajikan kembali dalam narasi/laporan kualitatif (Creswell, 2014). Smentara Miles dan Huberman menegaskan bahwa ada tiga tahapan dalam analisis data, yaitu : 


\section{Reduksi data (Data Reduction)}

Setelah data dikumpulkan, peneliti melakukan seleksi data sesuai dengan fokus penelitian. Data yang kurang relevan atau kurang berhubungan dengan fokus penelitian direduksi agar lebih mudah dalam meringkas dan membuat abstraksi terhadap data mentah, sehingga menjadi jelas. Reduksi data ini merupakan proses pemilihan, memfokuskan pada penyederhanaan, pengabstraksian dan transformasi data mentah yang muncul dari data catatan-catatan tertulis dilapangan. Reduksi data merupakan bentuk analisis yang menajamkan hal-hal yang penting, membuang hal-hal yang tidak relevan dengan fokus penelitian agar sistematis dan bermakna.

2. Menyajikan data (Display Data)

Penyajian data merupakan proses penyampaian sejumlah informasi yang sudah disusun, yang memungkinkan untuk menarik kesimpulan dan pengambilan tindakan. Penyajian data merupakan gambaran secara keseluruhan dari sekelompok data yang diperoleh agar mudah dibaca secara menyeluruh:

Pada tahap ini data dapat disajikan dalam bentuk narasi, matriks, grafik dan didiskusikan dengan berbagai pihak dan sumber. Dengan menyajikan data, peneliti dapat memahami apa yang terjadi dalam penelitian baik menyangkut validitas data maupun hal-hal yang kurang dalam penelitian.

3. Membuat kesimpulan (Conclusion drawing/Verification)

Pada tahap ini peneliti membuat kesimpulan dan memverifikasi serta mencocokkan kembali pada data atau hasil lapangan atau menelaah dengan sejawat. Kemudian diproses agar menjadi data yang siap disajikan untuk selanjutnya dibuat kesimpulan hasil penelitian. Kesimpulan merupakan suatu konfigurasi yang utuh. Selanjutnya dijelaskan bahwa analisis data ini dilakukan semenjak pengurnpulan data, artinya tidak harus menunggu data itu terkumpul semua tetapi dalam waktu proses pengurnpulan data pun dapat dilakukan analisis data.

Adapun tools yang biasa digunakan untuk melakukan evaluasi pelatihan atau training yang sudah lazim ada 2 (dua) tools, yakni Return On Investment (ROI) atau biasa juga dikenal dengan istilah Return on Training Investment (ROTI) yaitu mengukur manfaat diklat dibandingkan dengan biayanya, serta The Human Resources Scorecard. Dan dalam penelitian ini, tools yang digunakan adalah The Human Resources Scorecard, karena dengan tools ini maka proses pembelajaran melalui training, dimana tools ini digunakan untuk mengukur dan mengevaluasi aktifitas sumber daya manusia termasuk didalamnya aktifitas pelatihan, khususnya untuk melakukan analisis terhadap perilaku dan hasil training.

Indikator dan variabel yang digunakan dalam evaluasi training, dengan mengunakan pendekatan Kirkpatrick dan tools ini, adalah sebagai berikut :

Tabel 1.

Indikator Evaluasi 


\begin{tabular}{ll}
\hline \multicolumn{1}{c}{ LEVEL } & \\
\hline Evaluasi level & 1. Pengelolaan waktu \\
1 (reaction) & 2. Pengunaan alat peraga \\
& 3. Materi training \\
& 4. Penguasaan materi oleh trainer \\
Level & 1. Memahami dan mentaati IK (Instruksi Kerja) \\
2 (Learning) & 2. Keahlian \\
Level & 1. Fokus \\
3 (Behavior) & 2. Kepedulian \\
& 3. Kedisplinan \\
& 4. Loyalitas \\
& 5. Kejujuran \\
& 6. Kemauan \\
& 7. Kreatifitas \\
& 1. Pengoperasian alat \\
Level 4 (result) &
\end{tabular}

\section{HASIL DAN PEMBAHASAN}

Proses pengembangan SDM atau karyawan di PT. Tridharma Kencana dilakukan melalui skema pengembangan yang cukup komperhensif, yakni dimulai dari perumusan kamus kompetensi dalam rangka menentukan people manajement. Dari People Manajement inilah, perusahaan melalui Departemen HRD kemudian merumuskan konsepsi dan kebutuhan bagi pengembangan karyawan, baik melalui training dan retensi karyawan. Dan ujungnya adalah dalam rangka melakukan promosi maupun mutasi karyawan.

Adapun skema pengembangan SDM di PT. Tridharma Kencana adalah sebagai berikut :

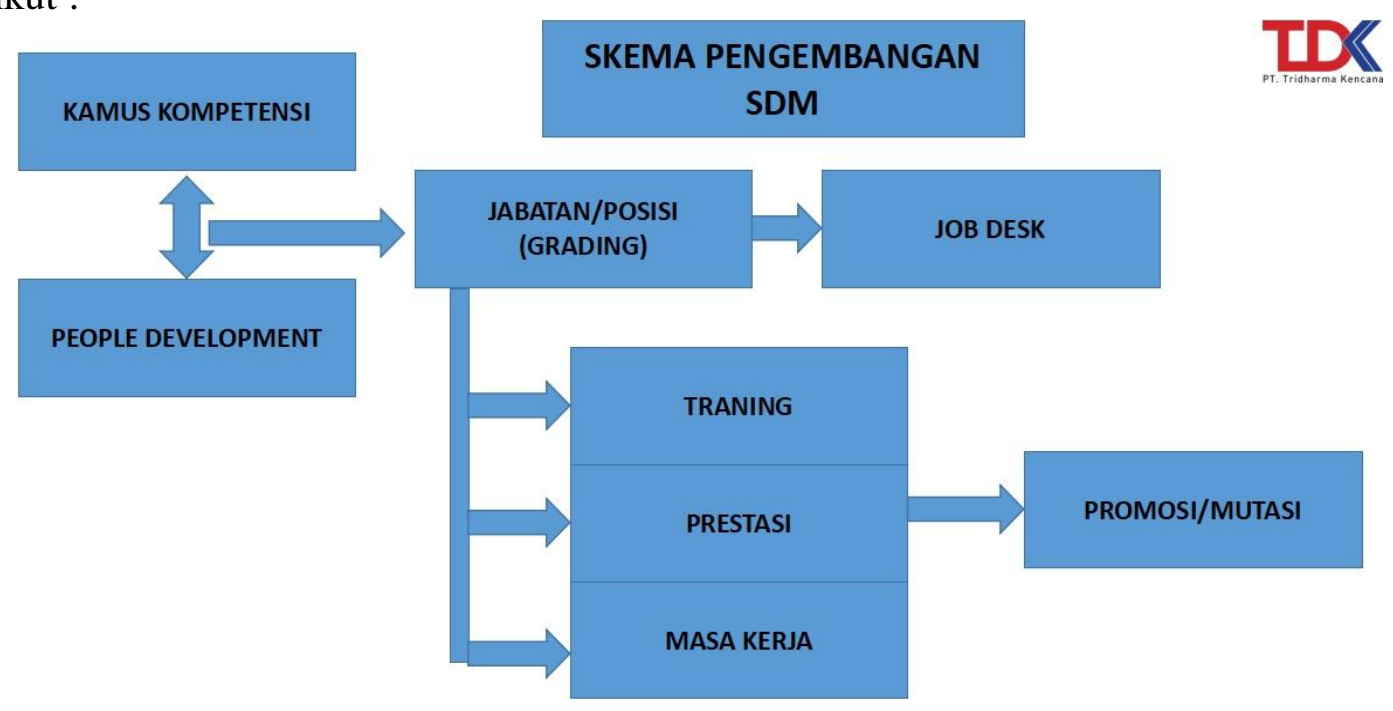

Gambar 1.

Skema Pengembangan SDM

Berdasarkan pada skema pengembangan tersebut, jelas bahwa training adalah bagian kecil dari pengembangan SDM (karyawan) yang selama ini berjalan di PT. 
Tridharma Kencana. Artinya, training bukan satu-satunya metode dalam pengembangan karyawan. Jika melihat dari skema tersebut, maka proses penentuan training juga menjadi cukup komperhensif, karena perumusannya berangkat dari Kamus Kompetensi dan People Manajement, yang menjadi basis utama pengembangan karyawan dan dasar dalam penentuan kebutuhan-kebutuhan job requarment di organisasi atau perusahaan.

Berdasarkan informasi yang diterima dari responden, bahwa training adalah tindak lanjut dari proses pengembangan SDM yang sudah dilakukan sebelumnya, yakni meliputi 3 (tiga) tahap pengembangan, yakni ;

\section{Metode Understudy}

Teknik pengembangan understudy serupa dengan metode on the job. Belajar dengan berbuat ditekankan melalui kebiasaan. Pada tehnik understudy tidak melakukan tugas secara penuh, tetapi diberikan tanggung jawab yang diberikan kepadanya. Dalam understudy, peserta diberikan latar belakang masalah dan pengalaman-pengalaman tentang suatu kejadian, kemudian mereka harus menelitinya dan membuat rekomendasi secara tertulis tentang masalah-masalah yang berhubungan dengan tugas-tugas unit kerja. Motivasi dan minat kerja pada umumnya tinggi apabila digunakan tehnik understudy. Konsep understudy memungkinkan perencanaan pegawai secara sistematis dan terkoordinasi serta dapat digunakan dengan jarak waktu yang lama.

2. Metode Job Rotasi.

Melibatkan perpindahan karyawan dari suatu pekerjaan pada pekerjaan lainnya. Kadang-kadang dari suatu penempatan pada penempatan lainnya yang direncanakan atas dasar tujuan belajar. Keuntungan job rotasi adalah antara lain karyawan mendapatkan gambaran yang luas mengenai berbagai macam jenis pekerjaan, mengembangkan kerjasama antar karyawan, menentukan jenis pekerjaan yang sanagt diminati oleh karyawan, mempermudah penyesuaiaan diri dengan lingkungan tempat bekerja, sebagai bahan pertimbangan dalam menentukan penempatan kerja yang sesuai dengan potensi karyawan.

\section{Metode Coaching-Counseling.}

Coaching adalah suatu prosedur mengajarkan pengetahuan dan ketrampilan. ketrampilan kepada karyawan. Counseling merupakan pemberian bantuan kepada karyawan agar dapat menerima diri, memahami diri dan merealisasikan diri, sehingga potensinya dapat berkembang secara optimal dan tujuan perusahaan dapat tercapai.

Setelah melewati 3 metode tersebut, tindak lanjut selanjutnya adalah melalui pelaksanaan training. Dimana proses identifikasi kebutuhan training bagi karyawan, dilakukan oleh tiap-tiap Departemen pada saat pelaksanaan Rapat Kerja Tahunan atau Annual Meeting yang dilakukan setiap awal tahun. Yang kemudian dirumuskan dalam program rencana kerja tahunan yang menjadi dokomen milik HRD Departemen.

Proses identifikasi kebutuhan yang dilakukan oleh departemen-departemen atau divisi-divisi terkait, harus dilakukan dengan memenuhi komponen utama yang 
dipersyaratkan oleh Departemen HRD, sekalu owner dari penyelenggara training yang notabene adalah menfasilitasi skema kebutuhan kompetensi karyawan.

Komponen prasyarat tersebut adalah :

1. Tujuan pelatihan.

Tujuan harus ditetapkan terlebih dahulu secara tegas spesifik, realistis, cukup menantang, diukur. Jelas batas waktunya, dirumuskan dengan kalimat singkat dan sederhana bahasanya agar mudah dicerna dan mudah ditangkap maknanya. Dengan demikian seluruh kegiatan training selalu akan terarah pada tujuan yang di tetapkan sebelumnya.

2. Peserta training.

Peserta dipilih yang sesuai dengan tujuan training, tidak terlalu heterogen baik dalam usia, pendidikan, maupun pengalaman kerja.

3. Trainer atau fasilitator.

Trainer yang dipilih adalah mereka yang sudah berpengalaman dan memiliki keterampilan dalam memberikan training. Sehingga trainer harus mampu menggunakan metode yang ada dan menguasai materi training dengan baik, serta mampu menjaga situasi dan suasana agar tetap keadaan yang menunjang pencapaian tujuan training.

4. Materi training.

Materi harus sesuai dengan tujuan training. Bahan bacaan disusun dengan bahasa yang sederhana agar mudah dimengerti dan dicerna oleh peserta.

5. Metode training.

Pemilihan metode training yang cocok akan mempermudah peserta menerima materi yang diberikan. Dengan demikian perubahan yang diharapkan dapat dicapai sesuai dengan tujuan training dan harapan peserta training.

Dari lima komponen itulah, kemudian diturunkan oleh Departemen HRD menjadi Program Training Tahunan. Berikut adalah contoh program Training tahunan untuk periode Tahun 2017. 


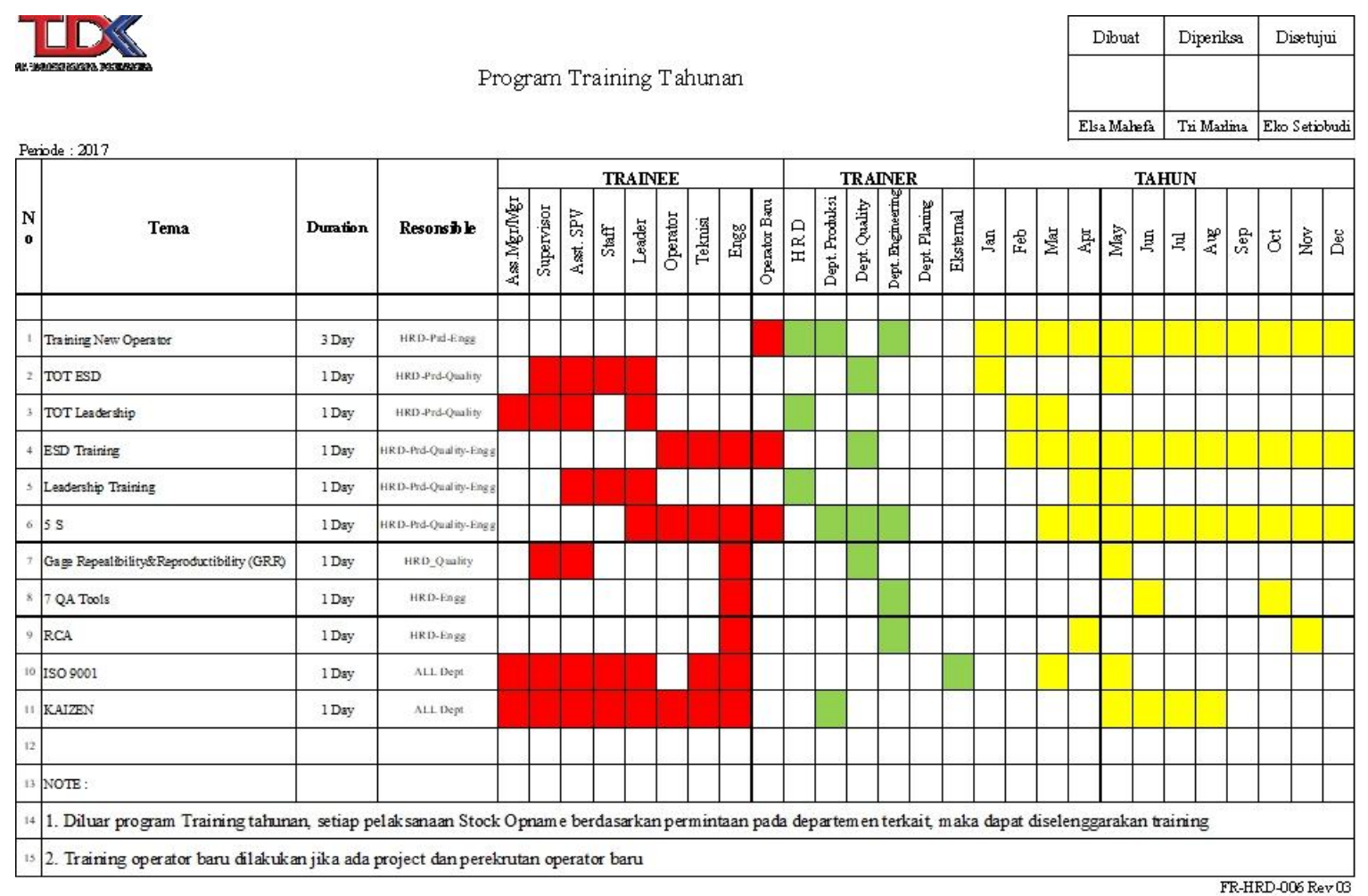

Gambar 2.

Tabel Program Training Tahunan Periode Tahun 2017

Dari program Training Tahunan tersebut, jelas kelihatan bagaimana pelaksanaan Training di PT. Tridharma Kencana sudah direncanakan dari awal tahun, dan program training tehunan tersebut berangkat dari kebutuhan-kebutuhan pengembangan karyawan yang ada di masing-masing departemen dan divisi. Penekanan ini penting, karena secara prinsip user karyawan adalah departemen dan divisi masing-masing. Sementara Departemen HRD hanya menfasilitasi kebutuhan-kebutuhan kompetensi di tiap-tiap departemen dan divisi, sehingga program pengembangan SDM melalui metode training dan pelatihan mampu diprogramkan secara sistematis dan sejalan dengan program pengembangan SDM dengan metode yang lainnya.

Hal lain yang tidak kalah penting dalam penyelenggaraan training adalah evaluasi pelaksanaan training serta penilaian dampak training kepada peserta training. Hal ini penting dalam rangka menjamin kualitas penyelenggaraan program training, maka diperlukan suatu fungsi kontrol yang dikenal dengan evaluasi untuk mengukur efektivitas training tersebut terhadap tujuan yang ingin dicapai.

Evaluasi training memiliki fungsi sebagai pengendali proses dan hasil program training sehingga akan dapat dijamin suatu program training yang sistematis, efektif dan efisien. Singkatnya, dengan dilakukanya evaluasi kita dapat melihat kembali proses training dan menilai hasil training serta dampak training yang dikaitkan dengan peningkatan kompetensi karyawan. 
Menurut (Kirkpatrick D. L., 2005) bahwa "evaluasi suatu training adalah bagian yang tidak terpisahkan dari penyelenggaraan training itu sendiri dan bahwa evaluasi tersebut merupakan kegiatan yang harus dilakukan agar training secara keseluruhan dapat berlangsung efektif”. Sebelumnya, (Kirkpatrick D. L., 2006) juga mengemukakan teorinya yang terkenal mengenai evaluasi training melalui tulisannya di American Society for Training and Development Journal. Menurutnya ada empat tingkat/level dalam evaluasi training, yaitu: (1) reaction, (2) Learning, (3) Behavior, dan (4) Result.

Evaluasi terhadap program training yang berjalan di PT. Tridharma Kencana meliputi empat level, yakni :

1. Evaluasi level 1 (reaction), bertujuan untuk mengetahui reaksi dan pendapat peserta tentang program training yang mereka ikuti.

2. Level 2(Learning), tujuan evaluasi yaitu untuk mengukur sejauh mana pemahaman peserta training atas materi (content) yang diberikan trainer (daya serap belajar).

3. Level 3 (Behavior), tujuan evaluasi training yaitu untuk mengetahui sampai sejauh mana program training yang diikuti oleh peserta dapat merubah behavior/perilaku karyawan di tempat kerjanya atau sejauh mana pengetahuan dan ketrampilan yang diperoleh dari hasil program training telah di terapkan di unit kerja masing-masing.

4. Level 4 (result), evaluasi bertujuan untuk mengetahui sejauh mana training yang dilakukan memberikan dampak/hasil (result) terhadap peningkatan kinerja peserta maupun perusahaan secara keseluruhan. Pada evaluasi level 4 (empat) ini dilakukan penilaian penilaian selama 3 minggu kemudian (3 minggu telelah pelaksanaan training), dengan metode penilaian secara mingguan.

Berdasarkan pada keempat level evaluasi tersebut, maka proses training selalu diarahkan untuk meningkatkan kompetensi karyawan baik soft skill kompetensi maupun hard skill kompetensi, membentuk tenaga-tenaga terampil, dinamis dan kreatif dengan tidak melepaskan diri dari dasar-dasar budaya kerja perusahaan dan lingkungan kerja yang kondusif dan nyaman.

Sementara dari aspek kualitas training dapat menunjuk pada kualitas proses dan kualitas produk yang dihasilkan. Dimana suatu training disebut berkualitas dari segi proses, jika proses pembelajaran yang bermakna, ditunjang oleh sumber daya (manusia, dana, sarana, prasarana) yang wajar. Logikanya, proses training yang berkualitas akan menghasilkan output produksi yang berkualitas pula. Oleh karena itu, intervensi sistematis diberikan terhadap prosesnya, sehingga memberikan jaminan kualitas pada produk yang memuaskan.

Sebagai bentuk implementasi dari program training tahunan, berikut adalah implementasi pelaksanaan training selama semester pertama tahun 2017 yang dilaksanakan di PT. Tridharma Kencana. 


\begin{tabular}{|c|c|c|c|c|c|c|c|c|}
\hline \multicolumn{9}{|c|}{ PELAKSANAAN TRAINING 6 BULAN PERTAMA TAHUN 2017} \\
\hline \multirow{2}{*}{ No } & \multirow{2}{*}{ JENIS TRAINING } & \multicolumn{6}{|c|}{\begin{tabular}{|c|c|c|c|c|c|}
\multicolumn{3}{c}{ BULAN } \\
\end{tabular}} & \multirow{2}{*}{ TOTAL } \\
\hline & & JANUARI & FEBRUARI & MARET & APRIL & MEI & JUNI & \\
\hline 2 & DISIPLIN WAKTU \& KERJA & $x_{2}$ & & $7 x$ & $1 \mathrm{x}$ & & & $\frac{9 \mathrm{X}}{1 \mathrm{X}}$ \\
\hline 3 & ESD & $1 \mathrm{X}$ & $2 \mathrm{x}$ & & $1 \mathrm{x}$ & $2 \mathrm{X}$ & & $6 \mathrm{x}$ \\
\hline 4 & ESD TOT & $2 \mathrm{x}$ & & & & & & $2 \mathrm{x}$ \\
\hline 5 & GRR & & & & & $1 \mathrm{X}$ & & $1 \mathrm{x}$ \\
\hline 6 & HANDLING MATERIAL & & & $2 \mathrm{x}$ & & & & $2 \mathrm{X}$ \\
\hline 7 & INTERNAL AUDIT QUALITY (ISO 9001:2015) & & & & & $1 \mathrm{X}$ & & $2 \mathrm{x}$ \\
\hline 8 & IINTERNAL AUDITOR ISO 9001:2015 & & & & & $1 \mathrm{x}$ & & $1 \mathrm{X}$ \\
\hline 9 & IT PROSES & & & & & $2 \mathrm{X}$ & & $2 \mathrm{x}$ \\
\hline 10 & KERJA SAMA TEAM & & & & $1 \mathrm{x}$ & & & $1 \mathrm{X}$ \\
\hline 11 & KOORDINASI \& TRAINING DISSASSEMBLY UNIT & & & $1 \mathrm{x}$ & & & & $1 \mathrm{X}$ \\
\hline 12 & LEADERSHIP & & & $3 \mathrm{x}$ & & & & $3 \mathrm{X}$ \\
\hline 13 & MANAGEMENT GRM + MATERIAL & & & $1 \mathrm{x}$ & & & & $1 \mathrm{x}$ \\
\hline 14 & MANAGEMENT NG & $1 \mathrm{x}$ & & $4 \mathrm{x}$ & $1 \mathrm{x}$ & & & $6 \mathrm{X}$ \\
\hline 15 & OPERATOR BARU & & $2 \mathrm{x}$ & & & & & $2 \mathrm{X}$ \\
\hline 16 & PEMAHAMAN SOP \& MANAGEMENT NG & & & & $1 \mathrm{X}$ & & & $1 \mathrm{X}$ \\
\hline 17 & PENEMPATAN BARANG & & & $1 \mathrm{x}$ & & & & $1 \mathrm{x}$ \\
\hline 18 & QUALTYY \& MANAGEMENT NG & & & & & & $1 \mathrm{x}$ & $1 \mathrm{x}$ \\
\hline 19 & QUALITY REQUAIREMENT & & & $2 \mathrm{x}$ & & & & $2 \mathrm{x}$ \\
\hline 20 & SECURITY AWARENESS & & & $1 \mathrm{x}$ & & $2 \mathrm{x}$ & & $3 \mathrm{x}$ \\
\hline 21 & TRAINING ISO 9001:2015 ( RISK MANAGEMENT) & & & & $1 \mathrm{x}$ & & & $1 \mathrm{X}$ \\
\hline & & & TOT & JUMLAH & RAINING 6 & ULAN PI & IMA 2017: & $49 \mathrm{X}$ \\
\hline
\end{tabular}

Gambar 3.

Tabel Pelaksanaan Training Semester I/2017

Berdasarkan pada gambar tersebut di atas, selama semester pertama tahun 2017, telah dilakukan 49 kali training. Dimana pelaksanaan training yang paling banyak yakni pada bulan Maret tahun 2017. Berdasarkan pada informasi yang diperoleh, banyaknya penyelenggaraan training pada Bulan Maret karena sejalan dengan hasil evaluasi bulanan yang sudah dilakukan pada periode bulan Januari dan Februari tahun 2017. Sementara jenis training yang paling banyak dilakukan adalah 5S training. Dimana menurut penjelasan responden, hal ini dilakukan dalam rangka menjaga konsistensi semua karyawan dan semua level karyawan untuk terus menekankan pelaksanaan 5S.

Penekanan pada 5S training juga menjadi bagian penting untuk membangun mainstream, awarness dan kesadaran bersama disemua lini, semua departemen dan semua divisi akan pentingnya menjadi kebersihan, keindahan dan kenyamanan di lingkungan kerjanya masing-masing. Kesadaran ini harus dilakukan setiap hari dan harus terus ditumbuh kembangkan setiap hari.

Terkait dengan evaluasi training, baik pada evaluasi level 1 (reaction), evaluasi level 2 (Learning), evaluasi level 3 (Behavior), dan evaluasi level 4 (result), dijelaskan sebagai berikut :

1. Evaluasi level 1

Pada level ini, indikator yang dilakukan penilaian adalah meliputi pengelolaan waktu, pengunaan alat peraga, materi training dan penguasaan materi oleh trainer. Indikator-indikator tersebut, kemudian diturunkan dalam betum Form Evaluasi Keefektifan Training, yang dibagikan kepada semua peserta training. Dimana semua peserta training harus mengisi form tersebut setelah pelaksanaan training selesai. Bobot penilaian dari tiap-tiap indikator yang dilakukan oleh peserta adalah VG (Very Good), G (Good), E (Enough) dan L (Less). Form evaluasi ini, berlaku untuk semua jenis training yang berjalan di PT. Tridharma 
Kencana. Dan berikut ditampilkan salah satu contoh hasil evaluasi training level 1 yang berjalan di PT. Tridharma Kencana, untuk jenis training 5S.

\begin{tabular}{|c|c|c|c|c|c|c|}
\hline \multicolumn{2}{|c|}{ Competence and Capacity } & \multirow{2}{*}{$\frac{\text { VG }}{19}$} & \multirow{2}{*}{$\frac{G}{12}$} & \multirow{2}{*}{$\frac{E}{1}$} & \multirow[t]{2}{*}{$\mathrm{L}$} & \multirow[b]{2}{*}{32} \\
\hline a & If the material provided very helpful in work activities & & & & & \\
\hline b & Trainer use or provide examples, tools / aids which correspond & 2 & 23 & 7 & & 32 \\
\hline c & Is time management is well managed & 4 & 22 & 6 & & 32 \\
\hline $\mathrm{d}$ & Trainer master the material presented & 7 & 16 & 9 & & 32 \\
\hline \multirow[t]{2}{*}{ e } & Trainer can give examples in daily activities & 9 & 16 & 7 & & 32 \\
\hline & & 41 & 89 & 30 & 0 & 160 \\
\hline
\end{tabular}

INFORMATION :

\section{Laporan Evaluasi Efektifitas Manajement NG Training}

Berdasarkan pada laporan evaluasi training tersebut, maka evaluasi pelaksanaan training meliputi beberapa indikator evaluasi, seperti materi, cara trainer menyampaikan materi, suasana atau kondusifitas pelaksanaan training, serta harapan peserta terhadap pelaksanaan training itu sendiri.

2. Evaluasi Level 2

Berikut adalah form isian evaluasi training untul level 2 :

Tabel 2.

\section{Form Evaluasi Level 2}

\begin{tabular}{|c|c|c|c|}
\hline INDIKATOR EVALUASI & BOBOT & TGL EVALUASI & KET \\
\hline $\begin{array}{lrr}\begin{array}{l}\text { Pemahaman } \\
\text { mengenai }\end{array} & \text { peserta } \\
\text { Kerja) } & & \\
\text { (Instruksi }\end{array}$ & 10 & & \multirow[t]{2}{*}{$\begin{array}{l}<100 \text { sangat baik } \\
80-60 \text { baik } \\
60-50 \text { buruk } \\
<50 \text { sangat buruk }\end{array}$} \\
\hline Keahlian & 10 & & \\
\hline
\end{tabular}

Berdasarkan pada indikator tersebut, penilaian evaluasi pada level 2 ini hanya 2 indikator, yakni pemahaman mengenai Instruksi Kerja dan Keahlian. Bobot dari masing-masing indikator adalah 10. Dan berikut adalah contoh hasil penilaian evaluasi untuk level 2. 


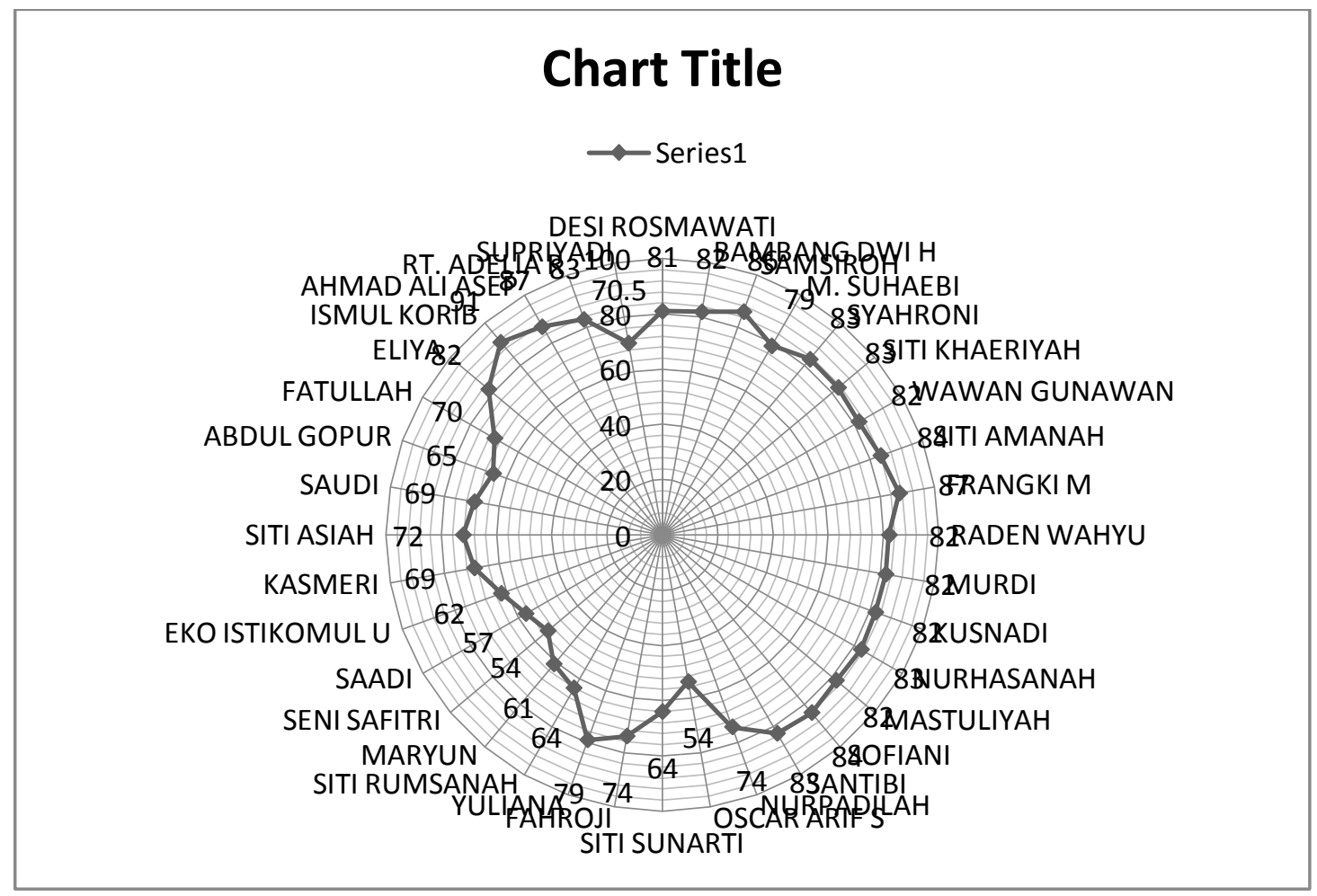

\section{Gambar 5.}

\section{Contoh Hasil Penilaian Evaluasi Level 3 Manajement NG Training}

3. Evaluasi Level 3

Pada evaluasi level 3, terdapat indikator evaluasi yang paling banyak, yakni :

Tabel 3.

Form Evaluasi Level 3

\begin{tabular}{|c|c|c|c|}
\hline INDIKATOR EVALUASI & BOBOT & TGL EVALUASI & KET \\
\hline 1. Tingkat Fokus (30\%) & & & $<100$ sangat baik \\
\hline \multirow{3}{*}{ - Tidak Berbicara dalam bekerja } & $30 \%$ & & $80-60$ baik \\
\hline & & & $60-50$ buruk \\
\hline & & & $<50$ sangat buruk \\
\hline 2. Tingkat Kepedulian $(10 \%$ & & & $<100$ sangat baik \\
\hline - Melakukan 5S & & & $80-60$ baik \\
\hline \multirow[t]{3}{*}{-Menjaga standar kualitas } & $5 \%$ & & $60-50$ buruk \\
\hline & & & $<50$ sangat buruk \\
\hline & $5 \%$ & & \\
\hline 3. Tingkat Kedisiplinan $(5 \%)$ & & & $<100$ sangat baik \\
\hline \multirow[t]{3}{*}{ - Ketepatan waktu bekerja } & & & $80-60$ baik \\
\hline & $5 \%$ & & $60-50$ buruk \\
\hline & & & $<50$ sangat buruk \\
\hline 4. Loyalitas (10\%) & & & $<100$ sangat baik \\
\hline - Kejujuran & $2 \%$ & & $80-60$ baik \\
\hline - Kemauan & $2 \%$ & & $60-50$ buruk \\
\hline - Kreatifitas & $6 \%$ & & $<50$ sangat buruk \\
\hline
\end{tabular}

Sumber: Diolah Peneliti 
Berikut adalah contoh rekapitulasi hasil evalusi untuk level 3 dan 4, yang peneliti terima.

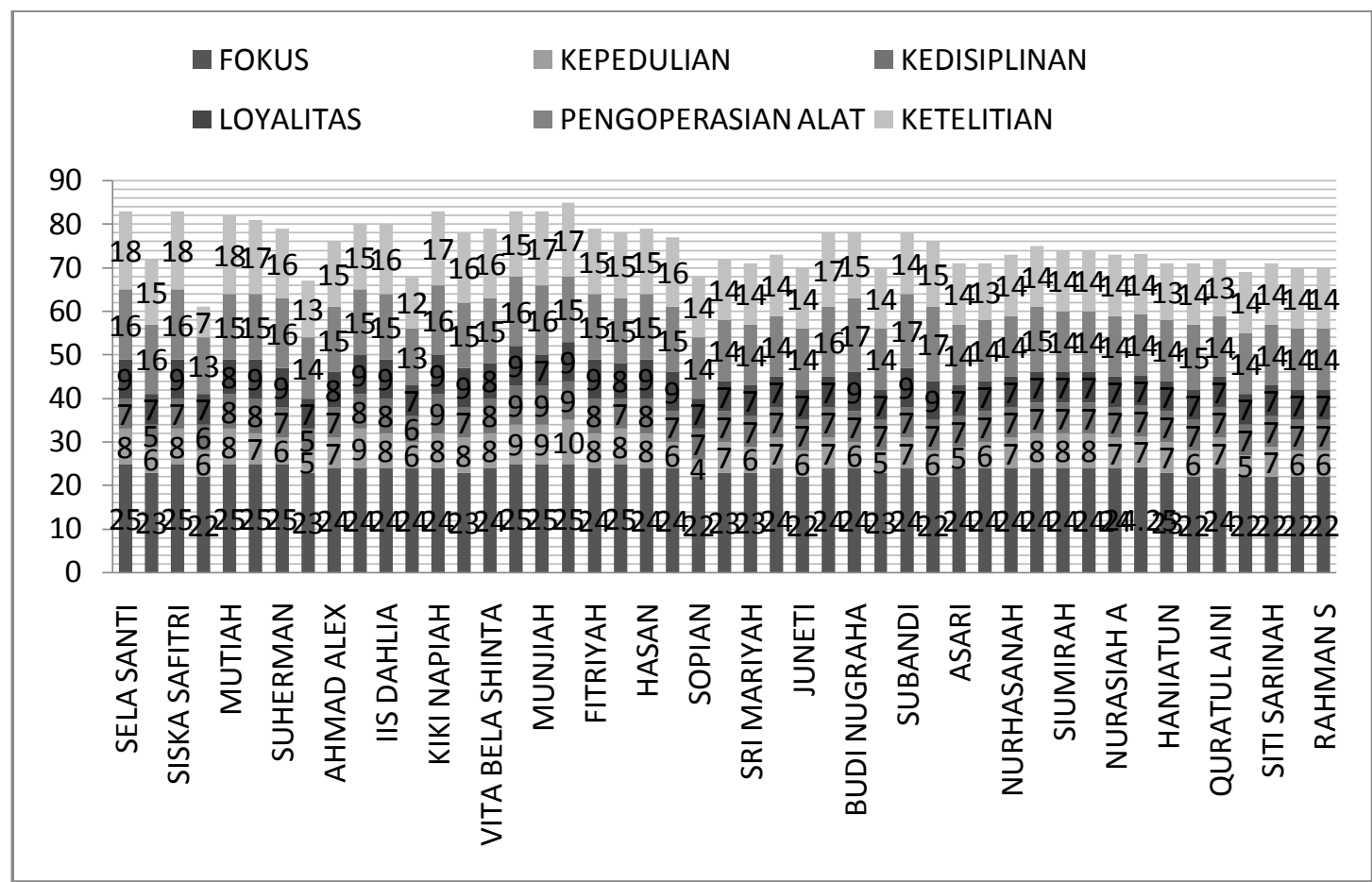

Gambar 6.

Contoh Rekapitulasi Evaluasi Level 3 dan 4 (Manajement NG Training)

4. Evaluasi Level 4

Indikator evaluasi untuk level 4 adalah :

Tabel 4.

Form Evaluasi Level 4

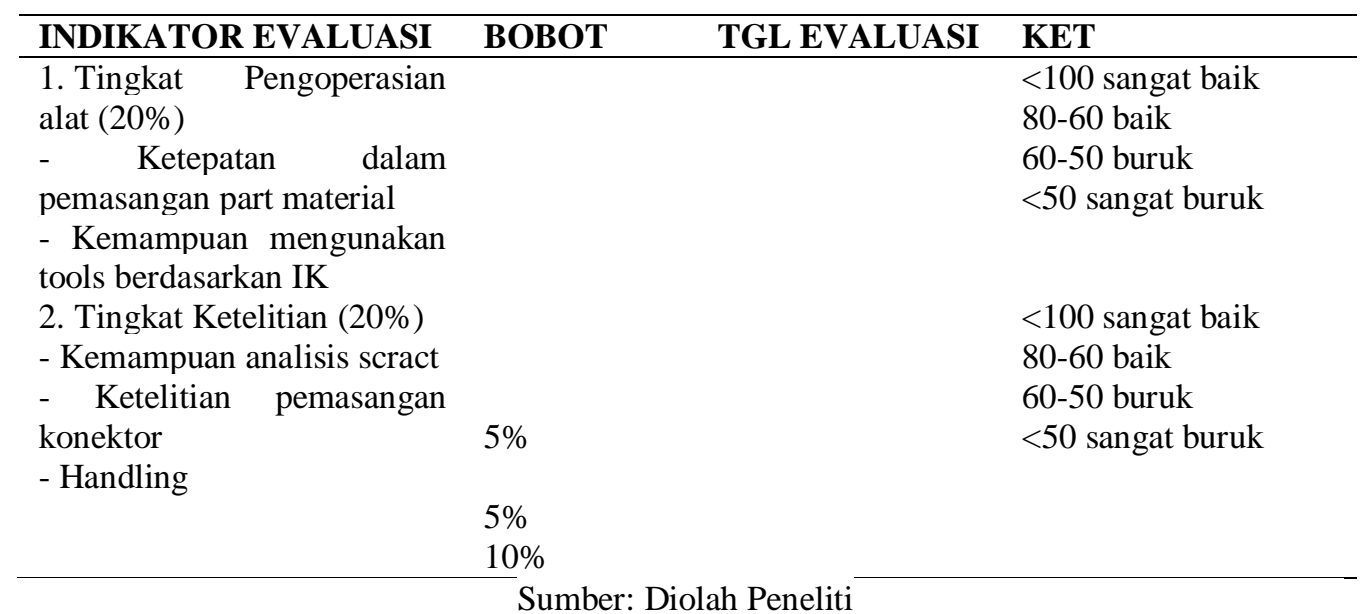


Berdasarkan pada form tersebut, berikut adalah contoh rekapitulasi evaluasi untuk level 4 ;

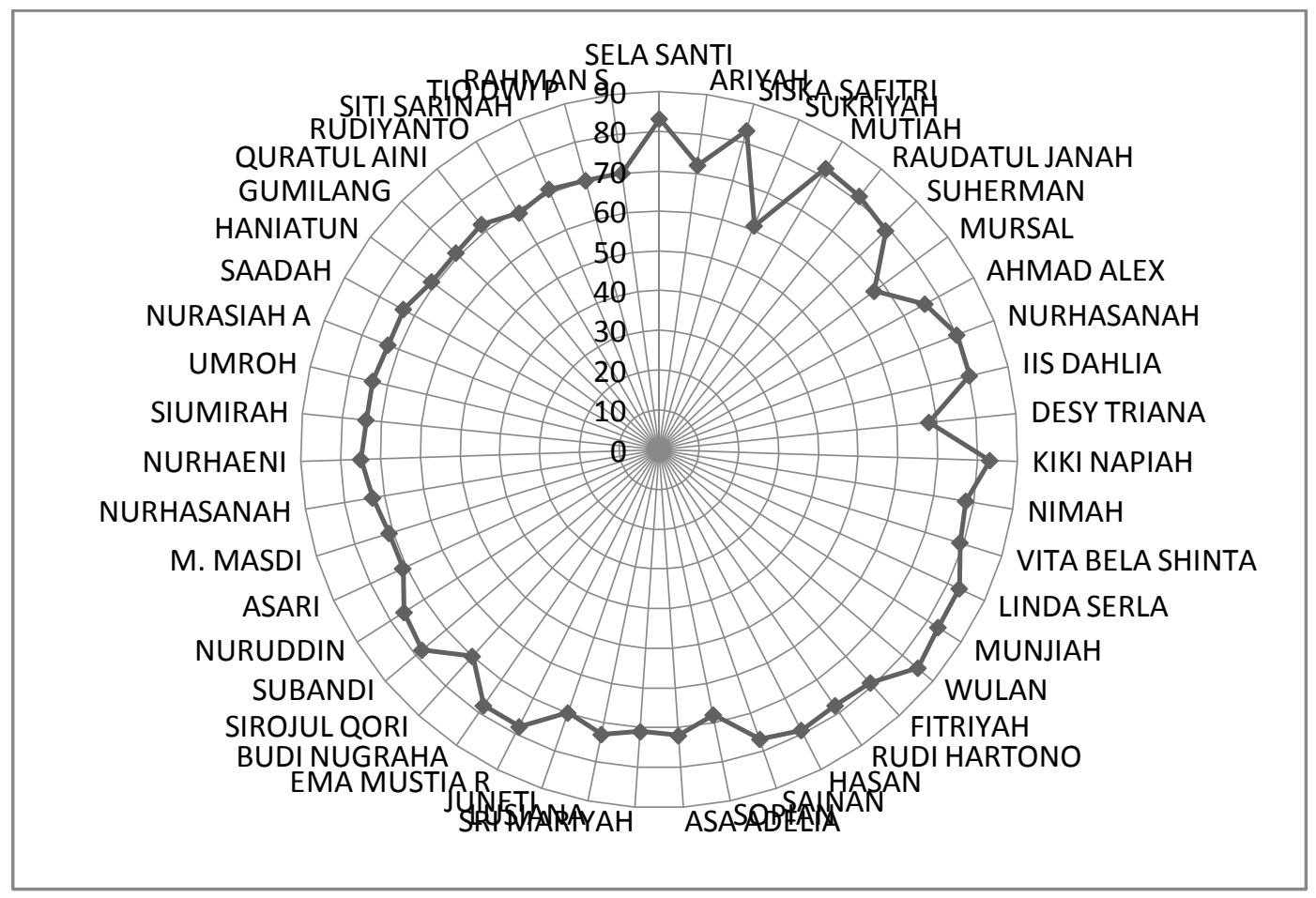

\section{Gambar 7.}

\section{Contoh Rekapitulasi Evaluasi Level 3 dan 4 (Manajement NG Training)}

Berdasarkan evaluasi-evaluasi baik dari level 1 - level 4 tersebut, kemudian disajikan dalam bentuk laporan result training yang adalah summary dari semua penilaian, dari level 1 sampai dengan level 4. Dan berikut adalah salah satu contoh dari summary result training yang diterima peneliti. 


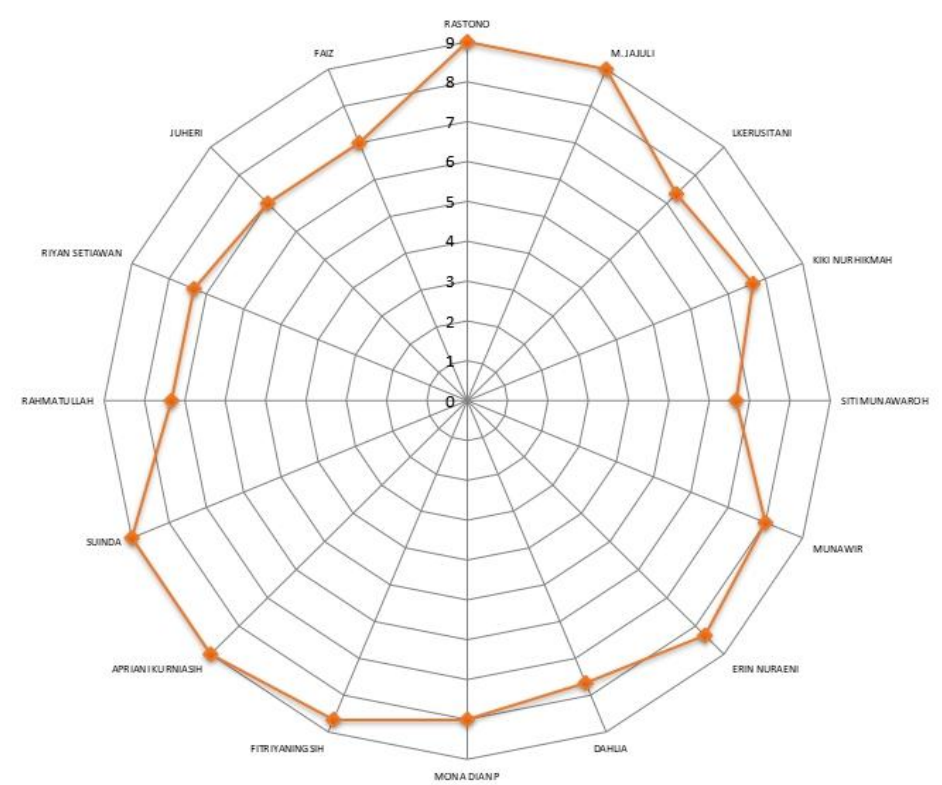

\begin{tabular}{|l|c|}
\hline Rekapitulasi : & \\
\hline VALUE (A) : & 4 \\
\hline VALUE (B) : & 11 \\
\hline VALUE (C) : & 1 \\
\hline VALUE (D) : & 0 \\
\hline TOTAL PASS: & 15 \\
\hline Re-Test : & 1 \\
\hline NOT PASS: & 0 \\
\hline
\end{tabular}

\section{Gambar 8. \\ Laporan Penilaian Result Training Leadership}

Hasil inilah yang kemudian menjadi acuan bagi HRD untuk menentukan lulus atau tidaknya karyawan dalam sebuah training. Apabila lulus (Value A dan B), maka akan menjadi dasar untuk mengikuti training selanjutnya yang telah diprogramkan oleh HRD dalam training tahunan, apabila Value C (training ulang) maka akan dilakukan training yang sama pada periode training selanjutnya, dan apabila tidak lulus (Value D) yang bersangkutan biasanya akan dilakukan penundaan untuk pemberian reward ataupun benefit.

Artinya, dengan skema pelatihan atau training yang demikian maka proses keberlanjutan training atau kelanjutan training menjadi terukur. Karena karyawan yang dapat mengukuti training lanjutan adalah karyawan yang sudah dinyatakan lulus training sebelumnya. Misalnya adalah bagi karyawan yang bisa mengikuti Management $N G$ training, adalah karyawan yang sudah dan dinyatakan lulus dalam 5S Training, ESD Training, GRR Training dan Management NG Training.

Adapun dari aspek proses penilaian dilakukan oleh atasan masing-masing, yang dalam hal ini adalah Asisten Supervisor maupun para Supervisor masing-masing peserta. Hal ini dilakukan karena Asisten Supervisor atau 
Supervisor yang secara hari-hari mengamati dan mendampingi para karyawan atau peserta training. Artinya, penilian ini dilakukan terkait dengan implementasi materi-materi training dalam kegiatan pekerjaan masing-masing peserta pada tiap-tiap departemen. Sehingga dengan skema penilaian yang dilakukan oleh Asisten Supervisor maupun Supervisor obyektifitas penilaian bisa dipertanggung jawabkan secara ilmiah dan akademis.

Dan pemilian ini dilakukan dalam praktek 3 minggu pasca training. Misalnya, pelaksanaan training pada Minggu Pertama, maka penilaian atau result praktek/implementasi di lapangan dilakukan pada minggu ke-2, minggu ke-3, dan minggu ke-4. Setelah itu hasil penilian diserahkan kepada Departemen HRD untuk di olah dan dilakukan analisa dan evaluasi dari palaksanaan training.

Menurut informasi yang diperoleh, konsep evaluasi training yang demikian, dilakukan agar Departemen HRD memperoleh ; (a) memperoleh dasar bagi pertimbangan kompetensi karyawan, (b) untuk menjamin cara kerja yang efektif dan efisien di semua lini pekerjaan, (c ) mendapatkan informasi mengenai kesulitan, hambatan, dan penyimpangan dari aspek-aspek tertentu dari semua instruksi kerja karyawan, (d) untuk perbaikan dan pengembangan kegiatan atau program training selanjutnya, dan ( e ) untuk melakukan diagnostik dan analisa terkait kebijakan program tahunan secara komperhnsif dan simultan.

Rekapitulasi hasil training yang berjalan selama satu bulan, kemudian dilakukan rekapitulasi di Departement HRD, baik mereka yang dinyatakan lulus training maupun mereka yang harus training ulang. Bagi pesserta training yang hasil penilaiannya dinyatakan lulus training, maka hasil training tersebut kemudian dijadikan sebagai :

1. Update kompetensi karyawan, baik soft skill kompetensi maupun hard skill kompetensi dalam people manajement.

2. Dasar untuk mengikuti training selanjutnya

3. Bagian dari skema penentuan grading karyawan

4. Bagian dari skema penentuan leveling karyawan

5. Bagian dari skema pemberian benefit dan retensi karyawan.

Pola yang demikian, dijalankan bagi semua karyawan di semua departemen, semua divisi dan di semua level karyawan. Dengan demikian, jelas bahwa program training yang selama ini berjalan di PT. Tridharma Kencana sudah berjalan cukup efektif, sebagai salah satu metode dan pendekatan dalam pengembangan SDM, khususnya dari aspek soft skill kompetensi maupun hard skill kompetensi. Dari hasil tersebut, diketahui juga bahwa selain sebagai bagian dari skema pengembangan SDM, juga menjadi bagian dari skema retensi (pemeliharaan) karyawan, yang kemudian diimplementasikan melalui mutasi maupun promisi karyawan.

Melalui model dan pendekatan yang demikian, maka obyektifitas dalam melakukan mutasi maupun promosi akan lebih proporsional, obyektif dan dapat dipertanggungjawaban secara ilmiah dan akademiki. Bukan semata-mata karena faktor dan alasan subyektif seperti kedekatan karyawan dengan pimpinannya. 


\section{E. SIMPULAN}

Pelaksanaan training yang berjalan di PT. Tridharma Kencana selama ini berjalan cukup baik. Dalam konteks ini, PT. Tridharma Kencana menerapkan bahwa training adalah salah satu program dari pengembangan SDM, yang notabene adalah aset perusahaan.

Artinya, PT. Tridharma Kencana sudah menempatkan training sebagai salah satu metode dan pendekatan dalam pengembangan SDM khususnya dari aspek kompetensi baik soft skill kompetensi maupun hard skill kompetensi. Hal ini salah satunya dibuktikan dengan banyaknya pelaksanaan training selama semester pertama tahun 2017, yakni sebanyak 49 kali training. Hal ini mengambarkan bahwa manajemen perusahaan menyadari pentingnya training sebagai salah satu pendekatan penting dalam rangka mendorong peningkatan kompetensi karyawan.

Evaluasi terhadap pelaksanaan training dilakukan melalui metode dan teknis Kirkpatrick, melalui 4 level evaluasi, yakni Level Reaction, Level Learning, Level Behavior, dan Level Result. Sehingga hasil training ditempatkan sebagai bagian integral untuk mendorong kualitas penyelenggaraan training itu sendiri serta untuk mengukur dampak/ result training itu sendiri.

Dari aspek penilaian dan evaluasi, dengan melibatkan atasan karyawan seperti asisten supervisor maupun supervisor untuk melakukan penilaian dalam praktek di lapangan, maka sistem penilaian result training menjadi jauh lebih obyektif, karena asisten supervisor maupun supervisorlah yang sehari-hari berhadapan dan berhubungan secara langsung dengan para karyawan dalam menjalankan pekerjaanya.

\section{DAFTAR PUSTAKA}

Becker, B., Huselid, M. E., \& Ulchich, D. (2001). HR Scorecard: Menghubungkan orang, strategi, dan kinerja. Boston: Harvard Business School Press.

Bogdan, R., \& J, T. S. (1992). Pengantar Metode Penelitian Kualitatif. (A. Furhan, Trans.) Surabaya: Usaha Nasional.

Creswell, J. W. (2014). Research Design, Pendekatan Kualitatif, Kuantitatif dan Mixed (Terjemahan Edisi Ketiga). Yogyakarta: Pustaka Pelajar.

Emzir. (2012). Metodologi Penelitian Pendidikan Kuantitatif \& Kualitatif, Edisi Revisi,. Jakarta: PT Raja Grafindo Persada.

Kirkpatrick, D. L. (2005, 11 23). Learning Evaluation. Retrieved 11 23, 2005, from Business Ball: http://www.businessballs.com/kirkpatricklearningevaluasionmodel.html

Kirkpatrick, D. L. (2006). Evaluating Training Programs: The four levels. San Francisco: Berrett-Koehler Publisher. 
Marzuki, M. S. (1992). Strategi dan Model Pelatihan. Malang: IKIP Malang.

Moekijat. (1990). Evaluasi Pelatihan dalam Rangka Meningkatkan Produktivitas Perusahaan. Bandung: Penerbit Mandar Maju.

Nawawi, H. (1997). Manajemen Sumber Daya Manusia. Yogyakarta: Gajah Mada University Press.

Paul, A. K., \& R.N, A. (2003). Dampak Praktek Manajemen Orang pada Kinerja Organisasi: Analisis Model Kausal. International Juornal of Manajemen Sumber Daya Manusai, 156.

Spencer, N. L., \& Signe, M. (1993). Competence at Work : Models for Superrior Performance. New York: John Wily \& Son. Inc.

Straus, A., \& Corbin, J. (2003). Dasar-Dasar Penelitian Kualitatif: Tata Langkah dan Teknik-Teknik Teorisasi Data. (M. Sodiq, \& I. Mutaqien, Trans.) Yogyakarta: Pustaka Pelajar.

Sudjana, N., \& Ibrahim. (2002). Penelitian dan Penilaian Pendidikan. Bandung: Sinar Baru Al Gensindo.

Sugiyono. (2011). Metode Penelitian Kuantitatif, Kualitatif, dan R\&D. Bandung: Alfabeta.

Wicaksono, Y. S. (2016). Pengaruh Pelatihan Dan Pengembangan Sumber Daya Manusia Dalam Rangka Meningkatkan Semangat Kerja Dan Kinerja Karyawan (Studi DI SKM Unit V PT. Gudang Garam. Tbk. Kediri), . Jurnal Bisnis dan Manajemen Vol. 3 No. 1 Tahun 2016, 123.

Wright, P. G., Moynihan, T., \& Allen, M. (2005). Hubungan antara Praktek SDM dan Kinerja Perusahaan: Memeriksa Urutan Kausal. Jakarta: Personil Psikologi. 